\title{
The Right Periphery of Interrogatives in Catalan and Spanish: Syntax/Prosody Interactions*
}

\author{
Sílvia Planas-Morales \\ Universitat Rovira i Virgili \\ Universitat de Barcelona. Grup de Recerca en Entonació i Parla \\ silvia.planas@urv.cat \\ Xavier Villalba \\ Universitat Autònoma de Barcelona \\ Centre de Lingüística Teòrica / Departament de Filologia Catalana \\ xavier.villalba@uab.cat
}

\begin{abstract}
It has been reported in the literature that interrogative sentences behave quite differently regarding subject-verb inversion in Spanish and Catalan: whereas the former allows 'classical' VS inversion, and particularly VSO, the latter systematically resorts to right-dislocation in all cases $(\mathrm{V}(\mathrm{O}) \# \mathrm{~S})$. In this paper we scrutinize this observation from a corpus-based perspective, and including into the syntactic picture the prosodic and pragmatic features of interrogatives. We show that Catalan interrogatives clearly favor RD, in sharp contrast with Spanish, which favors in situ realization of background material. This latter option has important consequences for the prosodic patterns of Spanish interrogatives, which mark final focus constituents with a pitch rising and that final background material with a slight pitch fall.
\end{abstract}

Keywords: interrogative sentences; right-dislocation; inversion; information structure; prosody; Catalan; Spanish.

* We thank two anonymous reviewers for helpful comments that have improved the final paper, and the first author expresses particular thanks to her colleagues of the Grup de Recerca en Entonació $i$ Parla (UB). Moreover, we are grateful to the editors of the volume, for their patience and expertise in the editing process. During the editing process Crocco (2013) appeared which considers partially similar data in Italian. Unfortunately, we could not include a discussion of this article. The research of the second author was partially possible due to research projects FFI2011-23356 (Ministerio de Ciencia e Innovación, Spain) and 2009SGR1079 (Generalitat de Catalunya), awarded to the UAB. 


\section{Table of Contents}
1. Introduction
4. Discussion
2. Methods
5. Conclusions
3. Results
References

\section{Introduction}

In his pioneering study of information packaging in Catalan and English (Vallduví 1992), Enric Vallduví challenged that the standard approach to Romance inversion (see Torrego 1984, Picallo 1984) could be applied to Catalan (fn. 72; see also Vallduví 2002: 4.1):

In Catalan, as noted, subjects may also be VP final or right-detached. In Spanish there seems to exist a process of subject-verb inversion that places the subject between the verb and the direct object (cf. Torrego 1984). This operation is not available in Catalan (cf. Picallo (1984) for dissent: this might be due to dialectal difference).

As a rule, Catalan interrogative sentences resort to $\mathrm{RD}$ where languages like Spanish show inversion. This fact can be easily appreciated comparing the different solutions for the last line of the following dialogue from Chester Himes' The Big Gold Dream in the Catalan and the Spanish translation (see section 2.1 for detailed references):

(1) «He stole your savings and ran away with a woman and you don't know who she is,» he said incredulously.

«Nawsuh, I never knew,» she said.

«And you didn’t do anything about it,» [he said sarcastically.]

(2) a. - I no hi va fer mai res, vostè?

and not LOC PST.3SG do never nothing you

b. - $-\mathrm{Y}$ tampoco hizo usted nada? and neither did.3sg you nothing

Here we can appreciate that whereas Catalan resorts to right-dislocation of the subject, Spanish favors the VSO inversion pattern (see Torrego 1984; Zubizarreta 1998; Ordóñez 1998, 2007; see also Picallo 1984 for a discordant view on the Catalan pattern). Moreover, as pointed out by Villalba and Mayol (2013: 95-96) (see also Mayol 2007: 212-213; Brunetti 2009: 4.2), Catalan use of right-dislocated subjects is pervasive, even in cases that one would expect dropping:

(3) a. Did you see it?

$$
\begin{aligned}
& \text { b. ¿L'has vist, tu? } \\
& \text { it+have.2sG seen you } \\
& \text { c. ¿Lo has visto? } \\
& \text { it have.2sG seen }
\end{aligned}
$$


(4) a. Did you believe her?
b. ¿Te l'has creguda tu?
REFL.2SG her+have.2SG believed.F you
c. ¿Crees lo que ella dijo?
believe.2SG it that she said

Here the pronominal subject appears right-dislocated in Catalan, and is omitted in Spanish. This omission is fully expected given that the pronoun denotes a highly salient referent in subject position (see Ariel 1991 for a general proposal in which null pronouns are high accessibility markers and thus, retrieve the most salient antecedents; see also Mayol 2010, Mayol and Clark 2010 for Catalan and Gutiérrez-Bravo 2007 for Spanish).

Hence, one can conclude that whereas Spanish interrogatives resort to subject-verb inversion or dropping of the subject, Catalan tends to right-dislocate it. Even though intuitively appealing, this statement of the issue is too vague and impressionistic to be considered a valuable empirical generalization suggesting an underlying pattern of microparametric variation. Henceforth, in this article we aim at filling this gap by means of a full-range study of interrogative sentences focused on their relation with RD and subject placement, and on their prosodic and pragmatic features.

Our method will be a comparative study of Catalan and Spanish interrogatives from a syntactic, prosodic and pragmatic perspective. Moreover, following the methodological path initiated by Mayol (2007) (see also Villalba 2007, 2011; Villalba and Mayol 2013), we will work with a written corpus and, as a novelty, with an oral corpus as well (see Font 2008 for the importance of oral corpora in the study of prosody), for it will help us to assess the accuracy of previous studies of the issue. Moreover, the comparative perspective will provide us with a better insight on the less prominent differences arising in the word order patterns of interrogatives. We explain the methodology of the study in section 2 . Then, in section 3 , we will present the results, which will guide our discussion in section 4. Finally, section 5 will close the article with the main conclusions of our study and further research issues.

\section{Methods}

\subsection{Data collection}

\subsubsection{Written corpus}

In order to find the closest minimal pairs between Catalan and Spanish, we chose two translations of Chester Himes' romance The Big Gold Dream (Pegasus, reprint edition 2008, original publication date: 1960):

- Chester Himes El gran somni daurat, Catalan translation by Carme Gerones and Carles Urritz (Barcelona, Ed. 62, 1989).

- Chester Himes El gran sueño de oro, Spanish translation by Carlos Peralta (Barcelona, Editorial Bruguera, 1981) 
The Catalan translation is a nice example of contemporary colloquial Catalan, which accurately reflects the popular lively dialogues of the original. In all the cases, page numbers correspond to the Catalan text quoted above, and the English translations of examples are from Chester Himes' original.

The Catalan text included 45 interrogative sentences with a right-dislocate, which corresponded to 43 interrogative sentences in the Spanish translation (2 Catalan sentences had no proper equivalent in the Spanish version).

\subsubsection{Oral corpus}

In order to explore the prosody of Catalan and Spanish interrogatives, the 45 interrogative Catalan sentences, and the 43 Spanish correlates were recorded by two native speakers with linguistic training with the open source phonetic software PRAAT (Boersma and Weenink 2010). Both informants read the sentences in a broad context and were allowed to rehearse their performance to fit their interpretation of the text.

All items were analyzed also with PRAAT to obtain their spectrograms and pitch contours (see 2.2.2).

\subsection{Variables studied}

\subsubsection{Syntax}

The syntactic variables considered were the following:

- Catalan Question type (C-Q-type): yes/no vs. wh-

- Catalan Question form (C-Q-form):

- For total interrogatives: zero/that

- For partial interrogatives: who/what/when/where/how/why

- Catalan Right-dislocate function (C-RD-function): subj/DO/IO/prep/locative

- Catalan subject position: zero/RD/SV/VS/VSO

- Spanish Question type (E-Q-type): yes/no vs. wh-

- Spanish Question form (E-Q-form):

- For total interrogatives: zero

- For partial interrogatives: who/what/when/where/how/why

- Spanish realization of Catalan Right-dislocate (S-RD-realization): zero/in situ/ $\mathrm{LD} /$ not available

- Spanish subject position: zero/RD/SV/VS/VSO

For the sake of clarity, consider one example and its coding (the right-dislocate is marked in boldface and the interrogative element in italics):

(5) a. - I què hi feia, a casa de Clayborne? — preguntà tot astut el sergent.

b. — ¿Y qué estaba haciendo en casa de Clayborne? —insinuó inteligentemente el sargento.

c. «What was he doing at Clayborne's house?» the sergeant slipped in cleverly. 
Table 1. Coding of item 5

\begin{tabular}{ccccccccc}
\hline$\#$ & $\begin{array}{c}\text { C-Q- } \\
\text { type }\end{array}$ & $\begin{array}{c}\text { C-Q- } \\
\text { form }\end{array}$ & $\begin{array}{c}\text { C-RD- } \\
\text { function }\end{array}$ & $\begin{array}{c}\text { C-S- } \\
\text { position }\end{array}$ & $\begin{array}{c}\text { E-Q- } \\
\text { type }\end{array}$ & $\begin{array}{c}\text { E-Q- } \\
\text { form }\end{array}$ & $\begin{array}{c}\text { E-RD- } \\
\text { real }\end{array}$ & $\begin{array}{c}\text { E-S- } \\
\text { position }\end{array}$ \\
\hline 5 & partial & what & loc & zero & partial & what & in situ & zero \\
\hline
\end{tabular}

All the coding related to the interrogative type and form, and the RD function was pretty obvious, and we followed standard practice. As for the subject position, zero meant subject drop, and when the subject was phonologically realized, we marked its position relative to the verb and the object, if present. In the case at hand, the subject was null in both languages.

Finally, concerning the Spanish realization of the right-dislocated constituent in Catalan, the options considered where very few: leaving aside very few cases where the Spanish version was too different to allow comparison, Spanish resorted to in situ realization, as in the example in (5) above, to null or overt pronouns (zero), as in (6) or to left-dislocation, as in (7).

(6) a. - Cago en dena! — exclamà en Sugar, de mala bava-. ¿I no se'n va al llit, vostè?

b. —Demonios — dijo con maldad—. ¿Por qué no se va a la cama?

c. «Hell,» Sugar said evilly. «Why don’t you go to bed.»

(7) a. —Què ve a ser, això? — preguntà ella.

b. -Y eso, ¿para qué es? — preguntó.

c. «What is that for?» she asked.

\subsubsection{Prosody}

The oral corpus was analyzed with the Melodic Analysis of Speech method (MAS), developed by Cantero (2002) and Cantero and Font (2009). MAS divides the melodic contour into the following melodic elements (see Figure 1):

- anacrusis: tonal segments preceding the first peak;

- first peak: initial prominence, which usually corresponds to the first stressed vowel or the unstressed vowel following it;

- body: tonal segments between the first peak and the last stressed vowel of the contour;

- nucleus: last stressed vowel (vowel with syntagmatic accent);

- final inflection (FI): tonal segments between the nucleus and the right-boundary of the contour.

The acoustic properties of these elements allow us to define the particular melodic contour of utterances for any sentence type.

To determine the relevant acoustic parameters of MAS, we obtained the $\mathrm{F}_{0}$ value of each vowel in Hertz, using PRAAT analysis software (Boersma and 


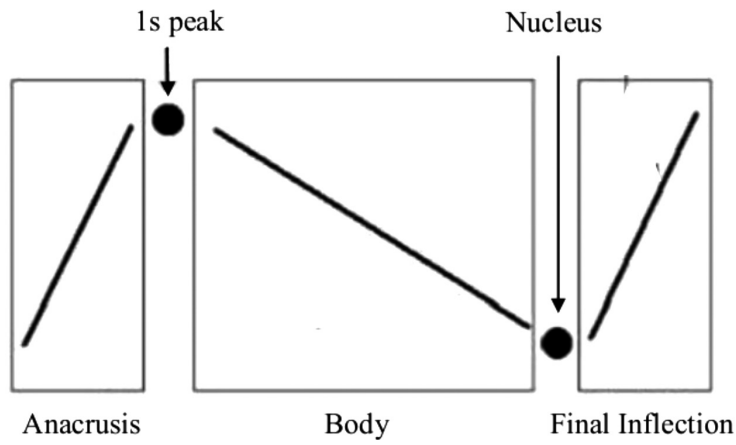

Figure 1. Melodic segments.

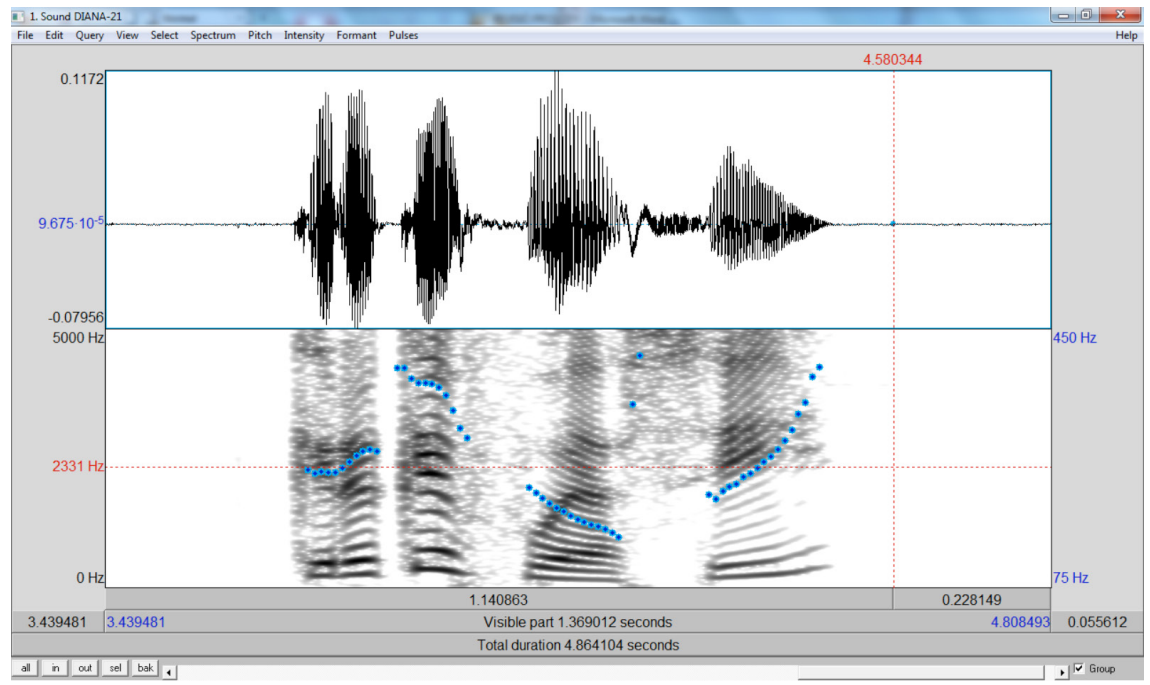

Figure 2. Waveform, spectrogram and melodic contour of Spanish sentence ¿Cree que fue así? 'Do you think it went this way?' with PRAAT analysis software.

Weenink 2010; see Figure 2). As for the final inflection, we calculated values from the beginning of the stressed vowel of nucleus until the end of the pitch contour.

However the pitch values obtained by acoustic analysis were not the contour melody, because MAS does not conceive melody as a succession of absolute pitch values, but rather as a succession of relative values (intervals) expressed as ratings $(\%)$ of pitch variation regarding the previous $\mathrm{F}_{0}$ value. Finally, we convert the percentage values into standard values, assigning the arbitrary value 100 to the first, as detailed in the following table: 
Table 2. Example of conversion of absolute pitch values into standard values

\begin{tabular}{llllllll}
\hline Utterance & $¿$ Cre & e & que & fue & a & sí? & sí? $^{\star}$ \\
Pitch $(\mathrm{Hz})$ & 241 & 273 & 370 & 216 & 147 & 207 & 376 \\
Percentages & $100 \%$ & $13,3 \%$ & $35,5 \%$ & $-41,6 \%$ & $-31,9 \%$ & $40,8 \%$ & $81,6 \%$ \\
Standard values & 100 & 113 & 154 & 90 & 61 & 86 & 156 \\
\hline
\end{tabular}

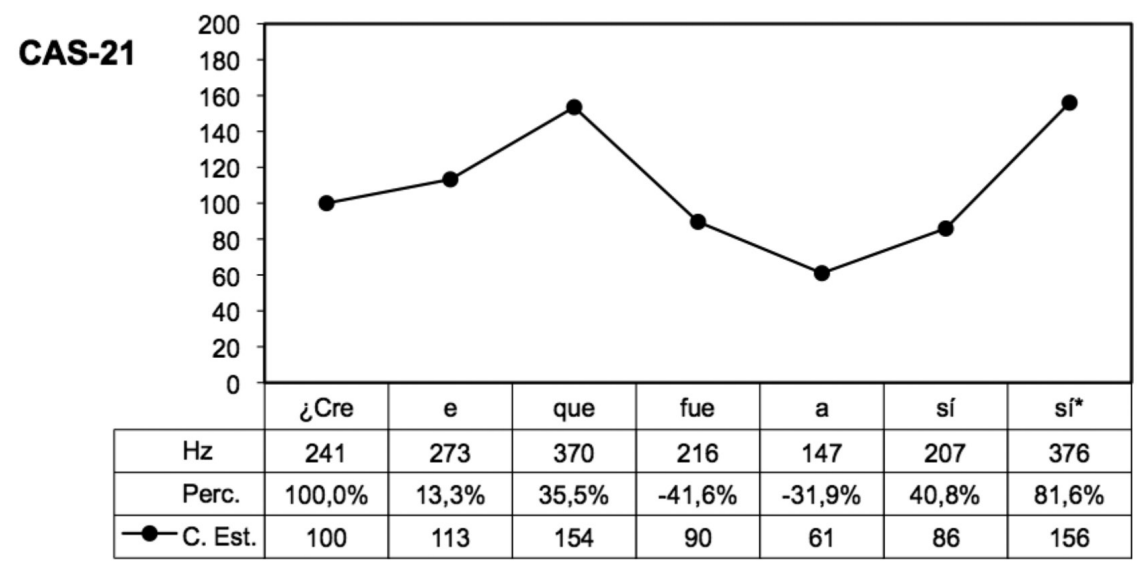

Figure 3. Standard melodic curve of Spanish utterance ¿Cree que fue así? 'Do you think it went this way?'

With these standard values, we can draw graphic representations (standard curves) of the melody contourns of each utterance (see Figure 3), which allow us to compare utterances regardless of the gender and age of speakers, for these variables affecting pitch values are filtered out in the transformation into standard values.

The MAS standard curves are thus a particularly well-suited method to build idealized melodic contours describing the major intonation features for each type of interrogative sentence (see subsection 3.2).

A final methodological caveat is needed. In this work, we divided standard curves of Catalan interrogatives into two phonic groups: the main sentence (PhG1) and the right-dislocate (PhG2) (see Figure 4). Even though, this is an innovation regarding previous work in the MAS framework (since no specific attention was paid to dislocates), this dual intonational phrasing of utterances involving a rightdislocate has proven to be empirically adequate for Catalan by Prieto (2002), and Feldhausen (2010: ch. 5). 


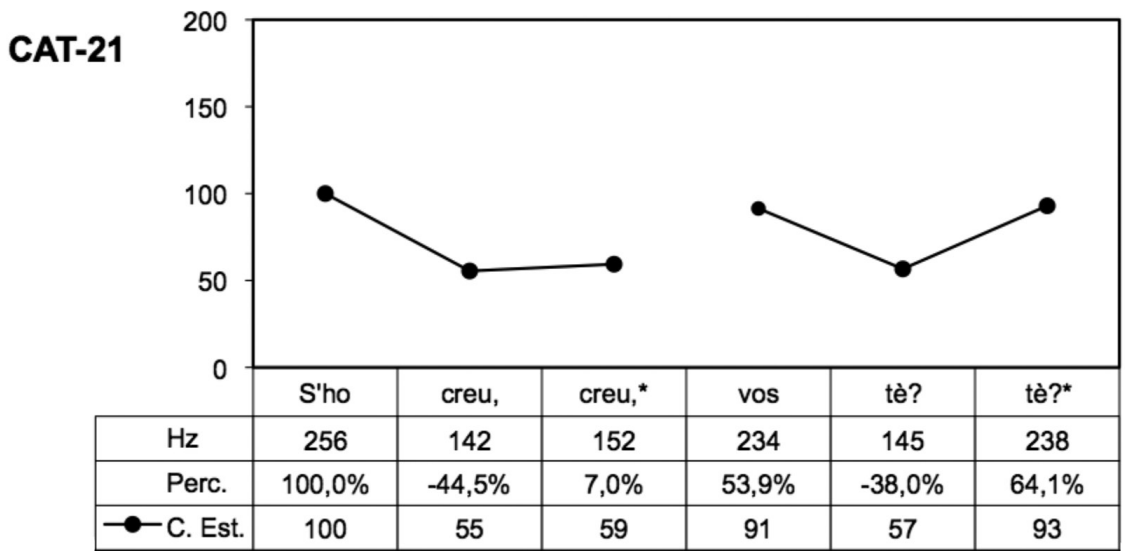

Figure 4. Standard melodic curve of Catalan sentence S'ho creu, vostè? 'Do you believe it?' (You believe her? in Himes' original).

\subsubsection{Pragmatics}

Our study of the pragmatics of interrogatives followed the typology of Escandell Vidal (1999: 61.4-5), from which we took five categories: questions, confirmations, requests, exclamative interrogatives, and rhetoric questions. Let us briefly present each type.

The prototypical function of interrogatives as QUESTIONS is self-evident: they are used for obtaining some information.

(8) a. Què vols per sopar?

what want.2sG for dinner

'What do you want for dinner?'

b. Tens gana?

have.2sG hunger

'Are you hungry?'

Secondly, we included CONFIRMATION as a separated category from standard questions, even though a close one. The following Spanish example provides us with a clear case:

(9) - Sabes que también han matado al judío, ¿verdad? know.2sG that also have.3PL killed to-the jew true

'You know the Jew has been killed, too?'

The third category was REQUEST, as in the following case from the Spanish translation: 
(10) ¿Por qué no se va a la cama?

for what not REFL go.3SG to the bed

'Why don't you go to bed?'

The fourth category included EXCLAMATIVE INTERROGATIVES, namely interrogatives that convey a surprising attitude of the speaker toward a fact that is common knowledge. For instance, in a context where the hearer just entered the room, the following interrogative about this obvious fact gets a surprise interpretation:
(11) Ja has tornat?
already have.2SG came back
'You already came back!'

The last category considered was RHETORIC QUESTIONS, understood in the standard sense of interrogative sentences implicating the truth of the equivalent asserted sentence with inverted polarity. Hence, the following interrogative (12a) conveys the assertion in (12b):

(12) a. Que ho sabia jo, que eren polis? that it knew.1SG I that be.3PL cops 'How did I know you was the cops?'

b. Jo no sabia que eren polis.

I not knew.1sG that be.3PL cops

'I didn't know they were cops.'

\section{Results}

\subsection{Syntax}

\subsubsection{Interrogative form}

The Catalan translation contained 45 interrogatives with a RD, of which the $60 \%$ (27 occurrences) were wh-questions, and the $40 \%$ (18 occurrences) were yes-no questions. In the case of wh-questions, the most common wh-words were com 'how' (10 occurrences, 37.04\%) and què 'what' (8 occurrences, 29.63\%); see Table 3 for details. In the case of yes/no questions, there was an overwhelming preference for not including any marker (13 occurrences, $72.22 \%$ ), and a small amount of cases with the interrogative marker que 'that' (5 occurrences, $27.77 \%$ ).

The Spanish version maintained the proportions ( 2 occurrences were discarded for their Spanish translation was not comparable with the Catalan translation, hence the 43 items): it contained 29 wh-interrogatives (66.44\%) and 14 yes/no interrogatives $(32.55 \%)$, and the most common wh-words were cómo 'how' (14 occurrences, $48.27 \%$ ) and qué 'what' (7 occurrences, $24.13 \%$ ). In the case of yes/no questions, Spanish included no interrogative marker. 
Table 3. Frequency distribution of Catalan wh-words

\begin{tabular}{lcc}
\hline wh-word & $\#$ & $\%$ \\
\hline com 'how' & 10 & 37.04 \\
què 'what' & 8 & 29.63 \\
qui 'who' & 3 & 11.11 \\
on 'where' & 2 & 7.41 \\
quan 'when' & 2 & 7.41 \\
per què 'why' & 1 & 3.70 \\
quin 'which' & 1 & 3.70 \\
\hline Total & 27 & 397 \\
\hline
\end{tabular}

\subsubsection{Right-dislocate}

The 45 interrogative sentences included 21 occurrences of direct object RD (46.66\%), 18 subject RD (40\%), 4 locative RD (8.8\%), 1 indirect object RD $(2.22 \%)$ and 1 selected prepositional complement RD (2.22\%); see Table 4 for a detailed distribution:

When we considered the Spanish equivalents of Catalan RD, a clear strong preference was found for in situ realization in both yes/no and wh-interrogatives (52.94\% and $57.69 \%$, respectively), followed by dropping of the subject $(35.29 \%$ and $15.38 \%$, respectively). Moreover, subject inversion was only marginally present in yes/no interrogatives (5.88\%), and in a small amount in wh-interrogatives (11.54\%).

The Spanish realizations of Catalan RD were also coded for grammatical function, yielding two clear patterns. On the one hand, when the Catalan RD was a subject, Spanish preferred subject omission in the 10 of the 17 cases; on the other hand, when the dislocate was a complement (direct and indirect objects, and selected PPs), Spanish strongly preferred in situ realization: 21 of 23 occurrences). This preference was found for locatives as well: all 3 cases showed an in situ realization. The full frequency distribution is displayed in Table 6. 
Table 4. Frequency distribution of $\mathrm{RD}$ regarding syntactic function and type of interrogative

\begin{tabular}{|c|c|c|c|c|}
\hline & \multirow{2}{*}{$\begin{array}{c}\text { yes/no } \\
\#\end{array}$} & \multirow{2}{*}{$\begin{array}{c}\text { wh- } \\
\#\end{array}$} & \multicolumn{2}{|c|}{ Totals } \\
\hline & & & $\#$ & $\%$ \\
\hline DO & 8 & 13 & 21 & 46.66 \\
\hline Subject & 8 & 10 & 18 & 40.00 \\
\hline Locative & 0 & 4 & 4 & 8.80 \\
\hline 10 & 1 & 0 & 1 & 2.22 \\
\hline Prep & 1 & 0 & 1 & 2.22 \\
\hline Totals & 18 & 27 & 45 & 99.90 \\
\hline
\end{tabular}

Table 5. Spanish realizations of Catalan RD

\begin{tabular}{lccccc}
\hline & \multicolumn{3}{c}{ yes/no } & & \multicolumn{3}{c}{ wh- } \\
\cline { 2 - 3 } \cline { 5 - 6 } in situ & $\#$ & $\%$ & & $\#$ & $\%$ \\
zero & 9 & 52.94 & & 15 & 57.69 \\
pronoun & 6 & 35.29 & & 4 & 15.38 \\
(CL)LD & 1 & 5.88 & & 1 & 3.85 \\
VS(O) & 0 & 0.00 & & 3 & 11.54 \\
\hline Total & 1 & 5.88 & & 3 & 11.54 \\
\hline
\end{tabular}

Table 6. Frequency distribution of Spanish realizations of Catalan RD across functions

\begin{tabular}{|c|c|c|c|c|c|c|c|c|}
\hline & \multicolumn{2}{|c|}{ in situ } & \multicolumn{2}{|c|}{ zero } & \multicolumn{2}{|c|}{ LD } & \multicolumn{2}{|c|}{ Totals } \\
\hline & $\#$ & $\%$ & $\#$ & $\%$ & \# & $\%$ & $\#$ & $\%$ \\
\hline $\mathrm{DO}$ & 19 & 63.33 & 1 & 9.09 & 1 & 50.00 & 21 & 48.83 \\
\hline SUBJ & 6 & 20.00 & 10 & 90.90 & 1 & 50.00 & 17 & 39.53 \\
\hline LOC & 3 & 10.00 & 0 & 0.00 & 0 & 0.00 & 3 & 6.97 \\
\hline 10 & 1 & 3.33 & 0 & 0.00 & 0 & 0.00 & 1 & 2.32 \\
\hline Prep & 1 & 3.33 & 0 & 0.00 & 0 & 0.00 & 1 & 2.32 \\
\hline Total & 30 & 99.99 & 11 & 99.99 & 2 & 100 & 43 & 99.97 \\
\hline
\end{tabular}




\subsubsection{Subject position}

When we consider the realization of subjects, the contrast between Catalan and Spanish was very sharp: Catalan preferred RD (44.44\%) and null subjects (37.77\%), while Spanish overwhelmingly resorted to null subjects $(72.09 \%)$. As for subject inversion, it was just a $6.6 \%$ in Catalan, and without complements (no VSO or VOS), whereas it is three times more frequent (18.59\%) in Spanish.

The distribution is depicted even more clearly in Figure 5, where we represent the different solutions for each language, and all inversion cases are combined for the sake of comparison).

Table 7. Realization of subjects

\begin{tabular}{lrrrrr}
\hline & \multicolumn{3}{c}{ Catalan } & & \multicolumn{3}{c}{ Spanish } \\
\cline { 2 - 3 } \cline { 5 - 6 } RD & $\#$ & $\%$ & & $\#$ & $\%$ \\
LD & 20 & 44.44 & & 0 & 0.00 \\
Wh & 1 & 2.22 & & 2 & 4.65 \\
SV & 2 & 4.44 & & 1 & 2.32 \\
VS & 2 & 4.44 & & 1 & 2.32 \\
zero & 3 & 6.66 & & 4 & 9.30 \\
VSO & 17 & 37.77 & & 31 & 72.09 \\
VOS & 0 & 0.00 & & 3 & 6.97 \\
\hline Total & 0 & 0.00 & & 1 & 2.32 \\
\hline
\end{tabular}

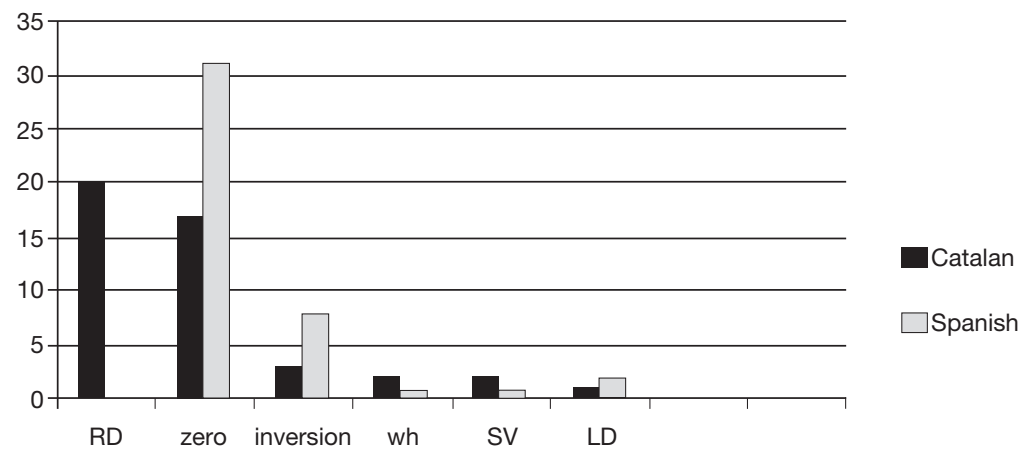

Figure 5. Realization of subjects. 
One can easily appreciate that Catalan preferred RD even over omission, which was the most common solution in Spanish (in accordance with the results reported by Villalba 2011 and Villalba and Mayol 2013). Moreover, it was clear from the data that inversion was three times more common in Spanish $(18.59 \%)$ than it was in Catalan $(6.66 \%)$.

\subsubsection{Interrogatives and $R D$}

No particular correlation was found between the kind of interrogative and the syntactic function of the RD: objects were the most frequent RD (44.44\% for yes/no and $48.14 \%$ for wh-interrogatives), closely followed by subjects $(44.44 \%$ for yes/ no and $37.03 \%$ for wh-interrogatives). See the details in Table 8 .

\subsubsection{Interrogatives and subjects}

There was no influence of the kind of interrogative in the realization of subjects in Catalan: RD was the most common option in both yes/no (44.44\%) and whinterrogatives (48.00\%), followed by dropping of the subject $(33.33 \%$ and $44.00 \%$ respectively). See the details in Table 9.

As for Spanish, a slight influence of the kind of interrogative was found: omission of the subject was more common in wh- $(77.77 \%)$ than in yes/no interrogatives (64.28\%). This pattern was reversed when inversion was considered: $28.57 \%$ in wh- and $14.81 \%$ in yes/no interrogatives. All values are reported in Table 10.

Table 8. Distribution of RD function regarding the kind of interrogative

\begin{tabular}{lcccccc}
\hline & \multicolumn{3}{c}{ yes/no } & & \multicolumn{2}{c}{ wh- } \\
\cline { 2 - 3 } \cline { 5 - 6 } & $\#$ & & $\%$ & & $\#$ & $\%$ \\
\hline direct object & 8 & 44.44 & & 13 & 48.14 \\
subject & 8 & 44.44 & & 10 & 37.03 \\
\hline locative & 0 & 0.00 & & 4 & 14.81 \\
indirect object & 1 & 5.55 & & 0 & 0.00 \\
\hline prepositional complement & 1 & 5.55 & & 0 & 0.00 \\
\hline Totals & 18 & 99.98 & & 27 & 99.98 \\
\hline
\end{tabular}

Table 9. Realization of subjects in Catalan interrogatives

\begin{tabular}{lccccc} 
& \multicolumn{3}{c}{ yes/no } & & \multicolumn{3}{c}{ wh- } \\
\cline { 2 - 3 } \cline { 5 - 6 } & $\#$ & $\%$ & & $\#$ & $\%$ \\
\hline RD & 8 & 44.44 & & 12 & 48.00 \\
zero & 6 & 33.33 & & 11 & 44.00 \\
inversion & 2 & 11.11 & & 1 & 4.00 \\
preverbal & 2 & 11.11 & & 1 & 4.00 \\
\hline Totals & 18 & 99.99 & & 25 & 100.00 \\
\hline
\end{tabular}


Table 10. Realization of subjects in Spanish interrogatives

\begin{tabular}{lccccc}
\hline & \multicolumn{3}{c}{ yes/no } & & \multicolumn{2}{c}{ wh- } \\
\cline { 2 - 3 } \cline { 5 - 6 } & $\#$ & $\%$ & & $\#$ & $\%$ \\
\hline RD & 0 & 0.00 & & 0 & 0.00 \\
zero & 9 & 64.28 & & 21 & 77.77 \\
inversion & 4 & 28.57 & & 4 & 14.81 \\
preverbal & 1 & 7.14 & & 2 & 7.40 \\
\hline Totals & 14 & 99.99 & & 27 & 99.98 \\
\hline
\end{tabular}

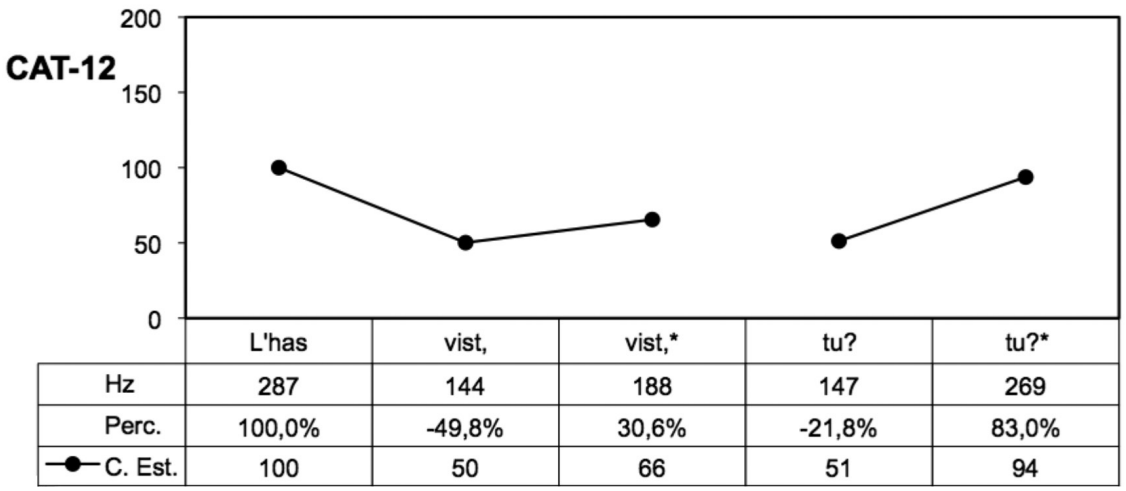

Figure 6. Standard curve of Catalan yes/no interrogative with a RD subject.

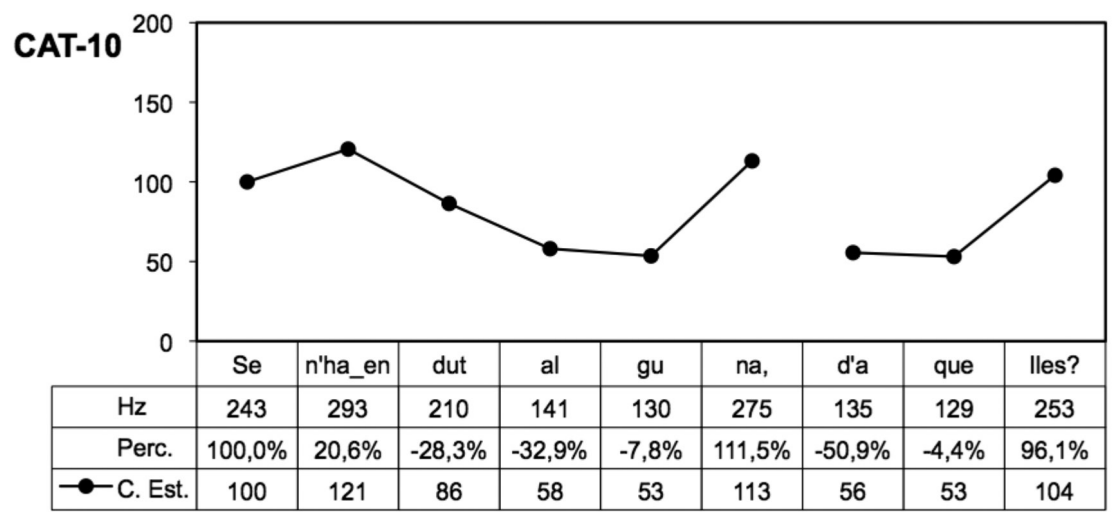

Figure 7. Standard curve of Catalan yes/no interrogative with a RD complement. 


\subsection{Prosody}

\subsubsection{Yes/no questions}

In Catalan yes/no questions, the phonetic group corresponding to the RD (PhG2) had a final inflection with a rise higher than the $60 \%$. As for the phonetic group corresponding to the clause $(\mathrm{PhG} 1)$, a difference was found regarding the function of the RD: when the RD was a subject, the final inflection of PhG1 showed a rising below the $40 \%$ (see Figure 6 ), but when the RD was a complement, the rising was superior to this $40 \%$ (see Figure 7 ).

We summarize the idealized melodic contours in Figure 8.

While adding the interrogative particle que 'that' did not affect the melodic contour of PhG2, which displayed a low decline in all cases, it did entail a clear lowering of the final inflection of PhG1, which amounted to more than a $40 \%$ descend in some cases (bigger then than that of declarative sentences; see Font Rotchés 2008).

Spanish yes/no interrogatives displayed the typical contour described in Escandell Vidal (1999: 61.4-5), and analyzed in Cantero and Font (2007): either a rising final inflection (Figure 9) or a descending-ascending one (Figure 10).

\subsubsection{Wh-interrogatives}

Catalan wh-interrogatives with a RD showed a final inflection for $\mathrm{PhG} 2$ with a maximum fall of $30 \%$, but PhG1 had a final inflection bigger than $30 \%$, and usually bigger than 40\% (see Figure 11 and Figure 12).

When PhG1 was concerned, small differences were found in the melodic contour regarding the function of the RD. On the one hand, subject and locative RD were closer to the standard wh-interrogative curve: the first peak was placed on the wh-word (Figure 11).

On the other hand, when RD was the direct object, the first peak moved from the wh-word to its right to the next tonal segment or even to become the nucleus (Figure 12).

This contrast is summarized in figures 13 and 14 .
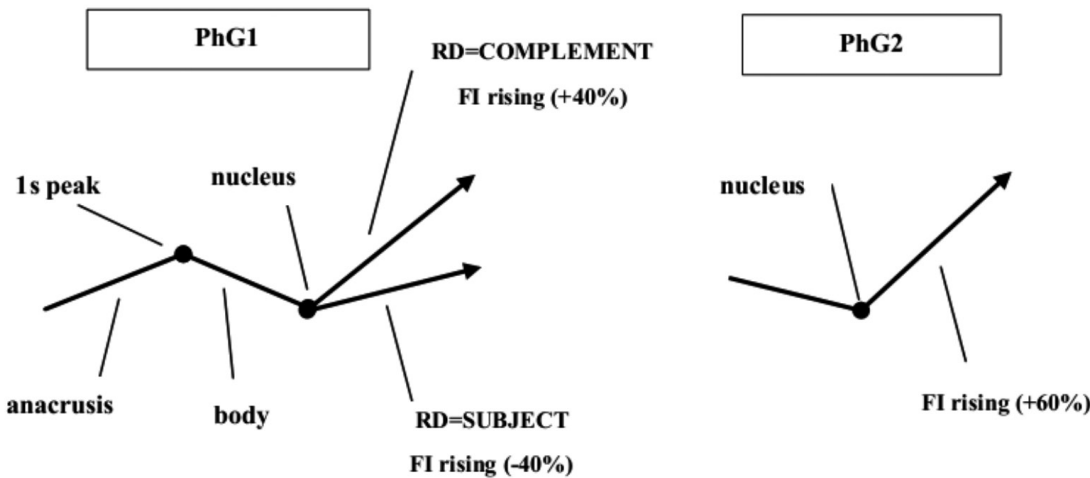

Figure 8. Idealized melodic contour of Catalan yes/no interrogatives. 


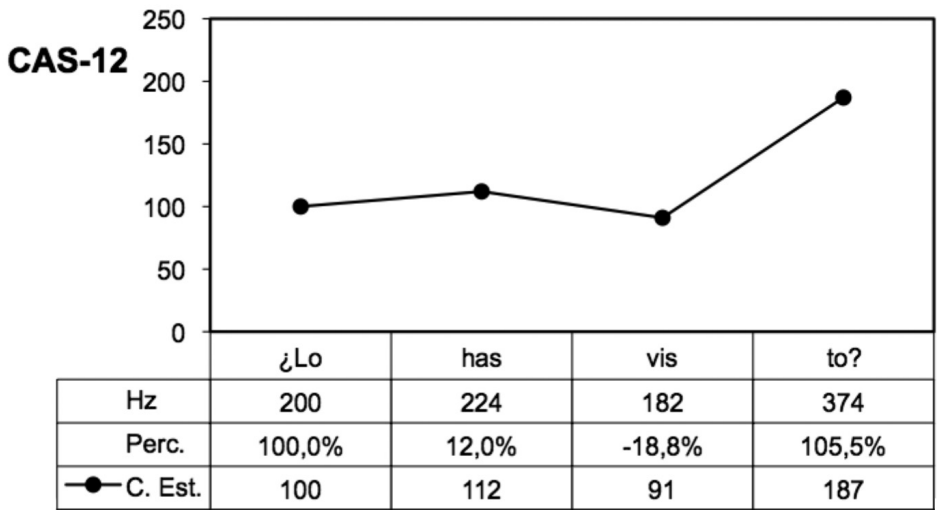

Figure 9. Standard curve of Spanish rising final inflection at yes/no interrogatives.

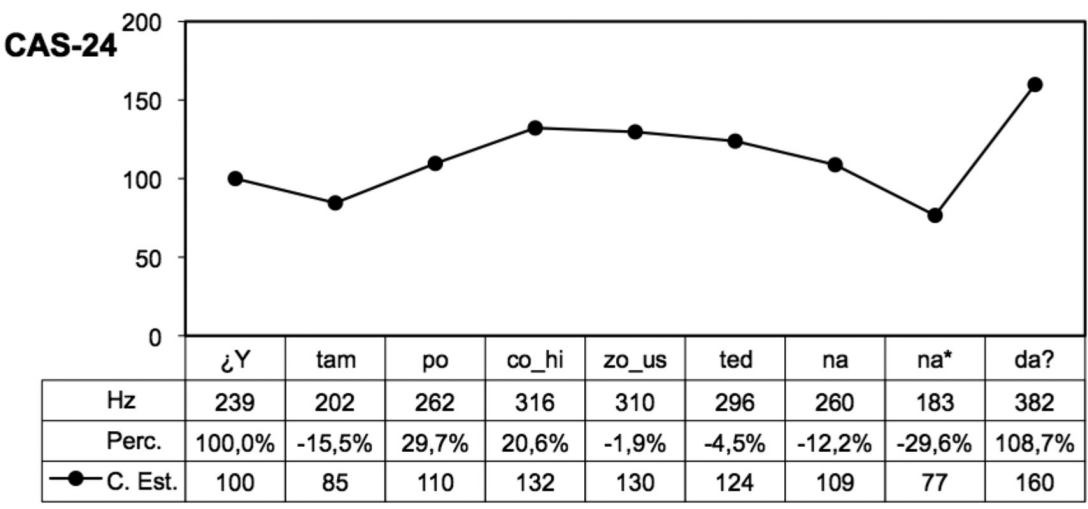

Figure 10. Standard curve of Spanish descending-ascending final inflection at yes/no interrogatives.

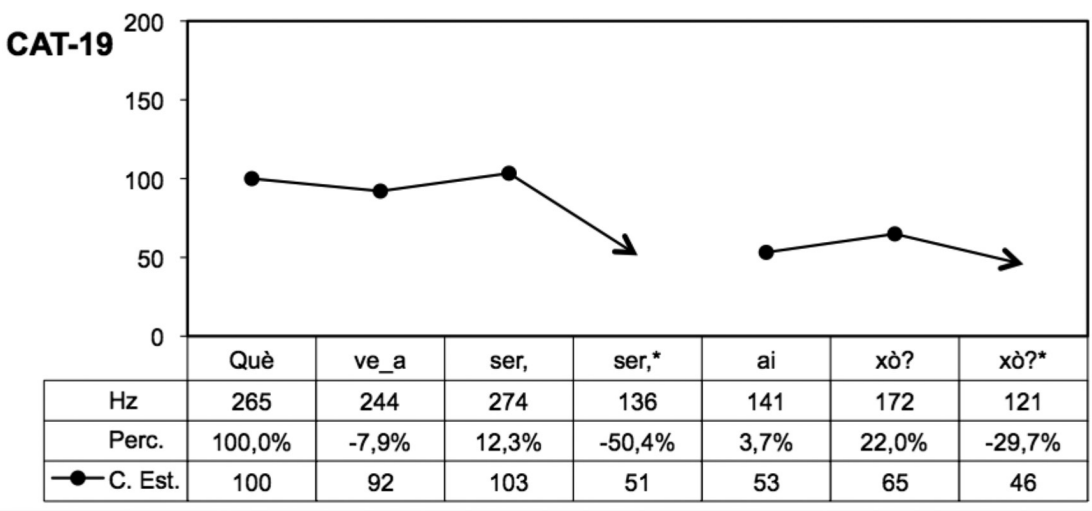

Figure 11. Standard curve of utterance Què ve a ser, això? (Catalan wh-interrogative with a $\mathrm{RD}$ subject). 


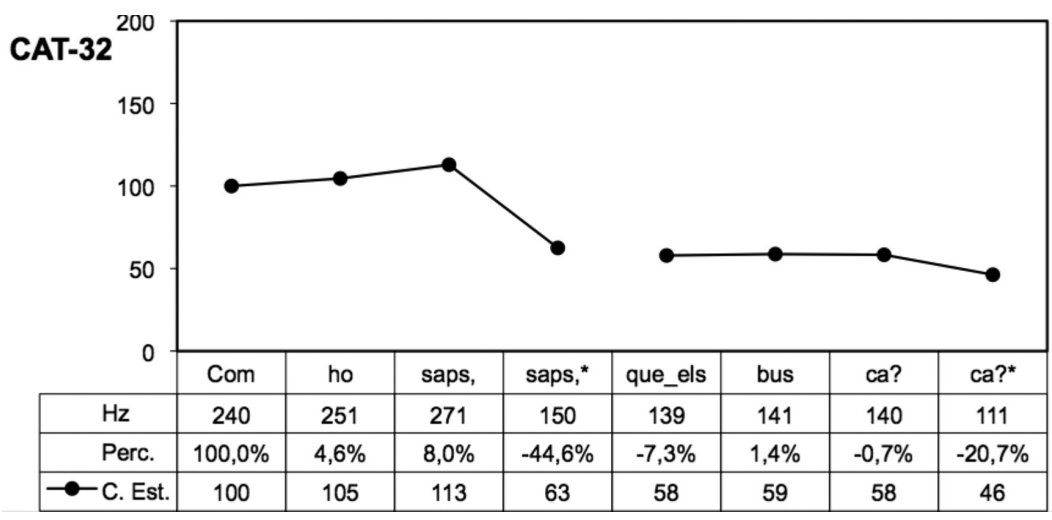

Figure 12. Standard curve of utterance Com ho saps, que els busca (Catalan wh-interrogative with a RD object).

\section{PhG1: Wh-word}

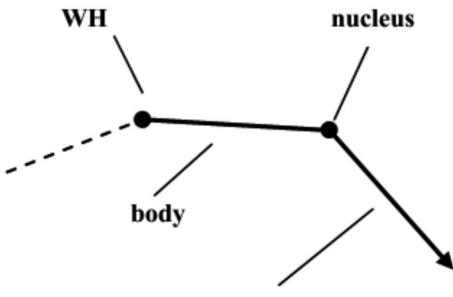

FI falling $(+30 \%)$

\section{PhG2: RD = Subject $/$ Locative}

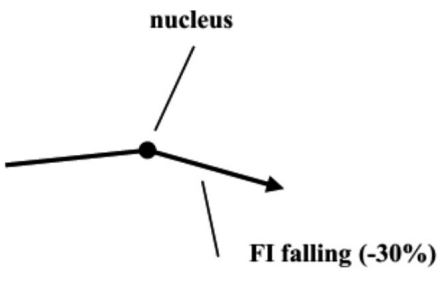

Figure 13. Idealized melodic contour of Catalan wh-interrogatives with a RD subject/locative.

PhG1: Wh-word

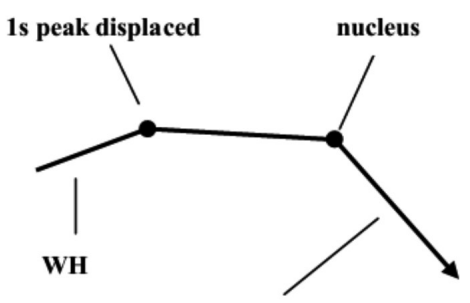

FI falling (+30\%)

\section{PhG2: RD = Object}

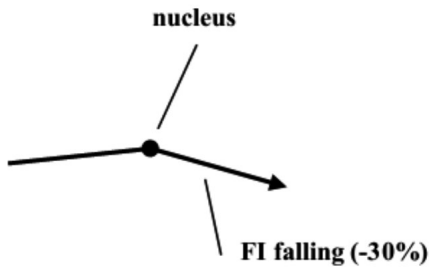

Figure 14. Idealized melodic contour of Catalan wh-interrogatives with a RD object. 


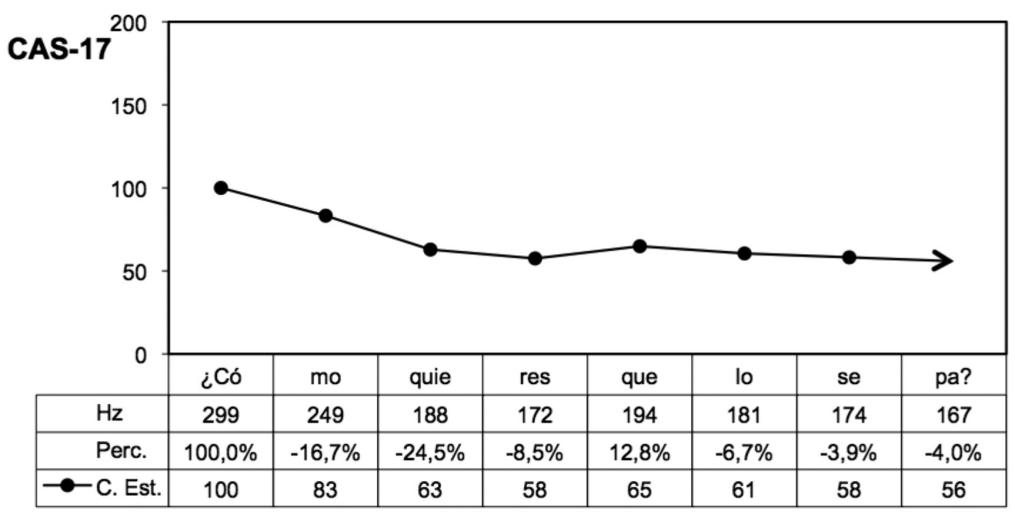

Figure 15. Spanish wh-interrogative with first peak on wh-word.

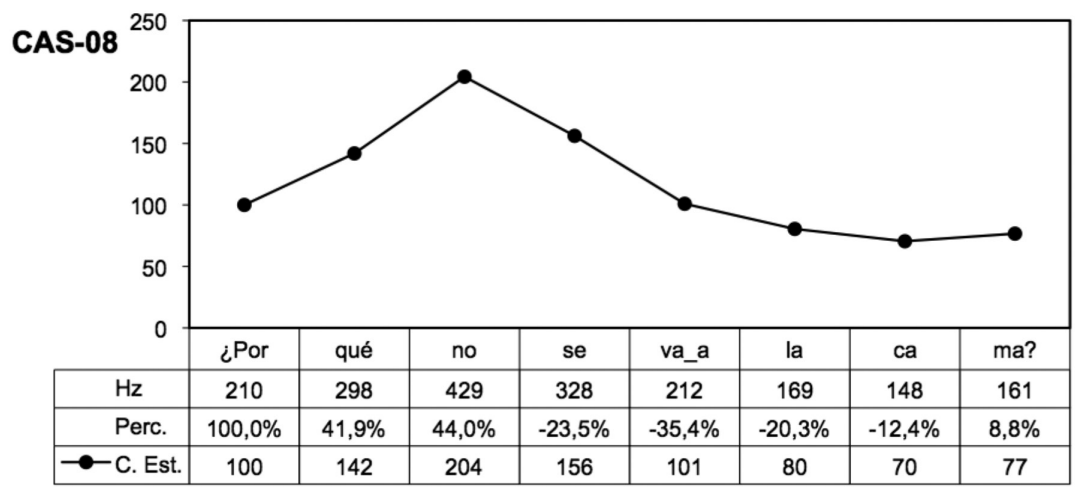

Figure 16. Spanish wh-interrogative with displaced first peak.

Spanish wh-interrogatives followed the typical melodic contour with a final descend, but with two main variants regarding the first part of the phonetic group. In one case, the wh-word was the first peak, which was followed by a fall until the end of the phonetic group (see Figure 15).

In the other unmarked case, the first peak is displaced to the next tonal segment, and a decline follows. This can be appreciated in Figure 16.

Both contours are summarized in Figure 17. 


\section{Contour A}

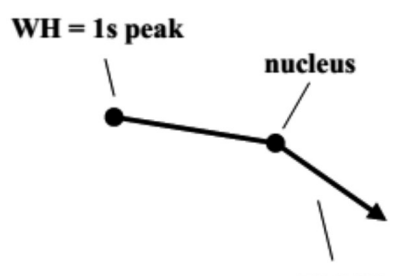

Contour B

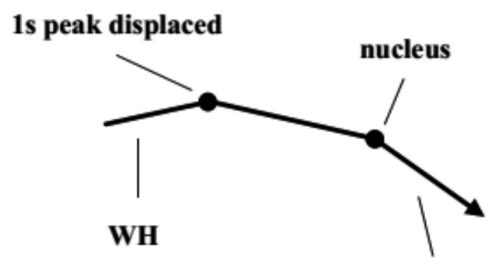

FI falling

Figure 17. Idealized melodic contours of Spanish wh-interrogatives.

\subsection{Pragmatics}

The pragmatic function of interrogatives was very similar in both languages. Notably, the question function was by far the most common option both for total and partial interrogatives: 72 of the 88 cases $(87.80 \%)$. The second most frequent option was a rhetoric value, which got only 7 cases $(7.95 \%)$. The other functions were almost insignificant. This distribution was consistent in both languages, as can be easily appreciated in Table 11 .

Moreover, in Table 11, one can see also that when the different kinds of interrogatives were considered, a clear tendency appeared: wh-questions were twice more common than yes/no questions in both languages.

As for yes/questions in Catalan, some specialization was found. On the one hand, among those introduced with que 'that' (5 occurrences), 3 were rhetoric and 2 questions. On the other hand, among those lacking any mark, 10 were questions, 2 exclamatives and 1 a request.

Table 11. Frequency distribution of interrogatives regarding pragmatic function

\begin{tabular}{|c|c|c|c|c|c|c|c|c|c|c|c|c|}
\hline & \multicolumn{2}{|c|}{ question } & \multicolumn{2}{|c|}{ rhetoric } & \multicolumn{2}{|c|}{ exclamative } & \multicolumn{2}{|c|}{ request } & \multicolumn{2}{|c|}{ confirmation } & \multicolumn{2}{|c|}{ Totals } \\
\hline & $\#$ & $\%$ & $\#$ & $\%$ & $\#$ & $\%$ & $\#$ & $\%$ & $\#$ & $\%$ & $\#$ & $\%$ \\
\hline C-wh & 24 & 88.88 & 2 & 7.40 & 1 & 3.70 & 0 & 0 & 0 & 0 & 27 & 99.99 \\
\hline S-wh & 25 & 86.20 & 2 & 6.89 & 1 & 3.44 & 1 & 3.44 & 0 & 0 & 29 & 99.97 \\
\hline C-yes/no & 12 & 66.66 & 3 & 16.66 & 2 & 11.11 & 1 & 5.55 & 0 & 0 & 18 & 99.98 \\
\hline S-yes/no & 11 & 78.57 & 0 & 0 & 1 & 7.14 & 0 & & 2 & 14.28 & 14 & 99.99 \\
\hline Totals & 72 & & 7 & & 5 & & 2 & & 2 & & 88 & \\
\hline
\end{tabular}




\section{Discussion}

The data described in subsection 3.1 offer a new perspective on the behavior of Catalan and Spanish interrogatives regarding several variables.

\subsection{Syntax}

We can safely conclude that $\mathrm{RD}$ is a pervasive mechanism for marking background material in Catalan interrogatives even in the case of subjects, which one would expect to be simply omitted. In contrast, Spanish resorted to either dropping of the subject or realization of background material in canonical position. Henceforth, our study fully confirms the quantitative results published in Villalba (2007) and Villalba (2011) for declaratives.

However, an important comment is in order. As discussed in 3.1.2, direct object and subjects fared similarly as RD in both yes/no and wh-interrogatives, with a slight preference for the former (see tables 4 and 8). This result clearly contrasted with those reported in Villalba (2011: 1955): direct object RD doubled the number of subject RD: $50.44 \%$ vs. $25.22 \%$. This clearly suggests that the interrogative modality has a clear increasing effect in the rating of subject $\mathrm{RD}$, which empirically confirms the intuition expressed by Villalba and Mayol (2013: 96) that Catalan interrogatives favor RD.

\subsection{Prosody}

In 3.2.2, we have shown that the presence of $\mathrm{RD}$ had an influence in the prosodic pattern of Catalan wh-interrogatives: the final inflection showed an abrupt descend, in contrast with the pattern reported in Font Rotchés (2009), which involved a more moderate lowering of the pitch after the nucleus.

Yet the most important finding concerns the realization of background material in canonical position in Spanish. Villalba (2011: 1960) speculates that, since Spanish lacks oblique clitics, RD would be less regular a mechanism for marking background material than it is in Catalan. In contrast, realization in canonical position is maximally regular, for any category or function receives a similar treatment. Yet, he notes that this option would raise potential ambiguity between a focus constituent and a background one, unless additional prosodic mechanisms are involved (see Ziv 1994 for the original remark, concerning English), a point he could not test on his written corpus. In this respect, we can shed some light on the disambiguating role of prosody in Spanish comparing the melodic pattern of interrogatives with final focus and with final background.

Let us begin with a case with final focus. In the following dialog, the topic is the roll of bills, and in the last sentence (13f) the object DP a alguna chica 'any (other) chippy' is clearly in focus: 
(13) a. —De qué tamaño era el fajo? — preguntó Sepulturero.

«What size roll?» Grave Digger asked.

b. -No lo contaron.

«They didn't count it, boss.»

c. -Lo vieron.

«They saw it.»

d. - Sólo el borde: lo tenía bien apretado en el puño y apenas si les dejó ver el extremo.

«Just the edges, boss. He kept it gripped tight in his fist and just flashed the edges.»

e. Sepulturero y Ataúd Ed cambiaron una mirada.

«Grave Digger and Coffin Ed exchanged looks.»

f. — —Se llevó a alguna chica? — preguntó Ataúd Ed.

«Did he score with any other chippy?» Coffin Ed asked.

Consider the melodic pattern associated with this interrogative in Figure 18.

Here the body of the IntP shows a moderate rising until the final rising inflection typical of yes/no interrogatives. This pattern has been described in the literature as emphatic and it has been associated to expressive meanings of surprise or doubt (see Cantero 2002). However, we can advance a different hypothesis: the rising of the body contributes to mark the focus status of the last constituent.

If this is on the right track, we predict that yes/no interrogatives with a final background constituent, e.g. an in situ realization of a Catalan RD, should display a different melodic pattern, as suggested by Zubizarreta (1998). This prediction is confirmed in full. Consider the following case.

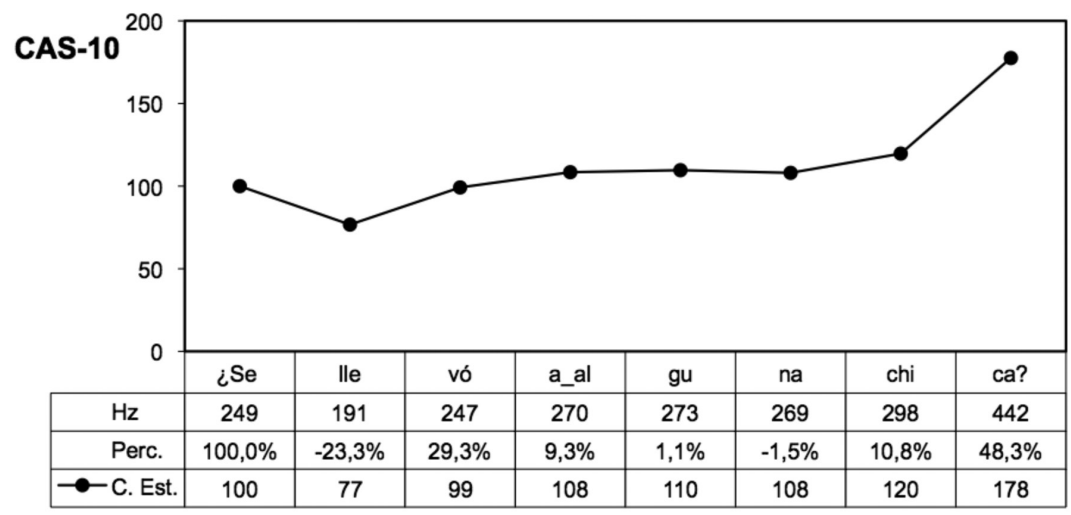

Figure 18. Spanish yes/no interrogative with sentence final focus. 
(14) — ¿Sabe algo la policía sobre el dinero que habías escondido? — preguntó el Dulce Profeta, cuyo pensamiento seguía ahora otro camino.

'«Do the police know about the money you had hidden?» Sweet Prophet asked her, his thoughts taking another tack.'

Here, the PP complement of saber 'know' in (14) is part of the background of sentence, since it has been explicitly introduced several paragraphs before (italics added):

(15) a. «No, my child, the sin was that you took this money which The Lord sent to you for the expiation of your sins and hid it for your own self, instead of bringing it to Sweet Prophet, who would have taken a share for The Lord, and returned you the rest in safety.»)

b. «How did you know I hid it?» Alberta asked in surprise.

Moreover, this constituent is realized as a $\mathrm{RD}$ in the Catalan version, clearly reinforcing the idea that it is not focus, but background.

Crucially for our purposes, the melodic pattern of this interrogative is sharply different from that in (13f), as can be appreciated in Figure 19.

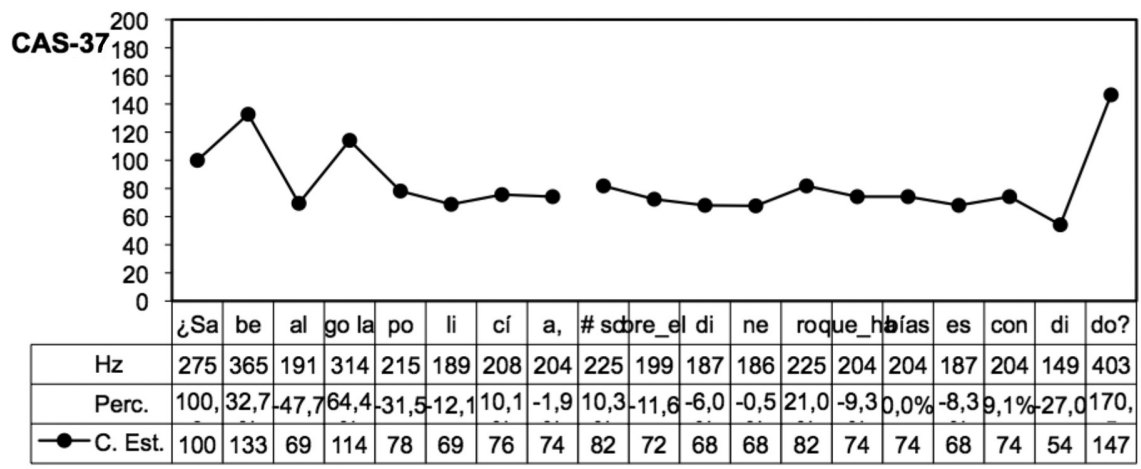

Figure 19. Spanish interrogative with sentence final background.

Here, the body of the PhG2 shows a clear progressive decline from the pitch baseline $(234 \mathrm{~Hz})$ until the final inflection (almost half the pitch value), which shows an abrupt rising. This lowering pitch profile of the body is in sharp contrast with the moderate rising found in the body of the interrogative when the constituent was in focus; see (13f) and Figure 18.

Obviously, a more detailed research is needed, which exceeds the scope of this article, but this seems a promising first step toward a principled explanation of the behavior of Spanish regarding the formal coding of the focus-background partition: the flexibility of Spanish intonation seems a crucial factor, confirming the seminal 
intuitions by Zubizarreta (1998). ${ }^{1}$ Moreover, we have clear empirical confirmation of Vallduví's intuition (Vallduví 1992, Vallduví and Engdahl 1996) that Catalan is a prosodic-rigid language, resorting to syntactic operations to mark the focusbackground partition of sentence (but see Forcadell 2007 for the disturbing role of Spanish interference).

\subsection{Pragmatics}

The pragmatic function of interrogatives did not have a clear influence on its form, for the canonical question function was overwhelmingly predominant regardless of the language and the kind of interrogative (see 3.3). Only Catalan yes/no interrogatives showed a slight deviation from this pattern: questions represented a $66.66 \%$, quite under the global $87.80 \%$, and rhetoric interrogatives a $16.66 \%$, clearly above the global 7.95\%; see 3.3. Moreover, even though numerically scarce an evidence, all Catalan yes/no rhetorical interrogatives were introduced by que 'that', suggesting a (weak) form-function connection.

\section{Conclusions}

In this article we have quantified the interaction of interrogative modality in Catalan and Spanish with the presence of $\mathrm{RD}$, and with the different syntactic, prosodic and pragmatic variables associated to this modality. After a comparative study of a written and oral corpus, we have confirmed and assessed the accuracy of previous intuitions expressed in the literature of the issue. Particularly, we have demonstrated that RD is even more common in Catalan interrogatives than in declarative sentences, that Spanish resort to realize background material in canonical position correlates with a specific prosodic pattern, and that the pragmatic function of questions does not has a clear correlation with their form, maybe with the partial exception of Catalan yes/no interrogatives.

\section{References}

Ariel, Mira (1991). «The function of accessibility in a theory of grammar». Journal of Pragmatics 16: 443-463.

Boersma, Paul; Weenink, David (2010). PRAAT. Doing phonetics by computer. Computer program.

Brunetti, Lisa (2009). «On links and tails in Italian». Lingua 119: 756-781.

Cantero Serena, Francisco José (2002). Teoría y análisis de la entonación. Barcelona: Edicions de la Universitat de Barcelona.

1. The melodic contours discussed raise an important methodological concern regarding studies on Spanish prosody: if the information status of elements has an influence on the prosodic contour of the sentence, a controlled focus-background pattern should be established before any analysis of interrogative contours is performed. 
Cantero Serena, Francisco José; Font Rotchés, Dolors (2007). «Entonación del español peninsular en habla espontánea: patrones melódicos y márgenes de dispersión». Moenia 13: 69-92.

Cantero Serena, Francisco José; Font Rotchés, Dolors (2009). «Protocolo para el análisis melódico del habla». Estudios de fonética experimental 18: 17-32.

Crocco, Claudia (2013). «Is Italian Clitic Right Dislocation grammaticalised? A prosodic analysis of yes/no questions and statements». Lingua 133: 30-52.

Escandell Vidal, Ma Victoria (1999). «Los enunciados interrogativos. Aspectos semánticos y pragmáticos». In: Bosque, Ignacio; Demonte, Violeta (dirs.). Gramática descriptiva de la lengua española. Madrid: Espasa, pp. 3929-3991.

Feldhausen, Ingo (2010). Sentential form and prosodic structure of Catalan. Amsterdam/Philadelphia: John Benjamins.

Font Rotchés, Dolors (2007). L'entonació del català. Barcelona: Publicacions de l'Abadia de Montserrat.

Font Rotchés, Dolors (2008). «Els patrons entonatius de les interrogatives absolutes del català central». Llengua i Literatura 19: 299-329.

Font Rotchés, Dolors (2009). «Les interrogatives pronominals del català central. Anàlisi melòdica i patrons entonatius». Els Marges 87: 41-64.

Forcadell, Montserrat (2007). Information packaging, language contact and linguistic change: structural calque in Catalan. Universitat Pompeu Fabra, doctoral dissertation.

Gutierrez-Bravo, Rodrigo (2007). «Prominence scales and unmarked word order in Spanish». Natural Language and Linguistic Theory 25: 235-271.

Mateo, Miguel (2010). «Análisis melódico del habla: protocolo para la automatización de la obtención de los datos de la curva estándar». Phonica 6 [electronic journal].

Mayol, Laia (2007). «Right-dislocation in Catalan: Its discourse function and counterparts in English». Languages in Contrast 7: 203-220.

Mayol, Laia (2010). «Contrastive pronouns in null-subject Romance languages». Lingua 120: 2497-2514.

Mayol, Laia; Clark, Robin (2010). «Pronouns in Catalan: Games of partial information and the use of linguistic resources». Journal of Pragmatics 42: 781-799.

Ordóñez, Francisco (1998). «The inversion construction in interrogatives in Spanish and Catalan». In: Lema, José; Treviño, Esthela (eds.). Theoretical analyses on Romance languages. Amsterdam: John Benjamins, pp. 329-350.

Ordóñez, Francisco (2007). «Cartography of postverbal subjects in Spanish and Catalan». In: Baauw, Sergio; Drijkoningen, Frank; Pinto, Manuela (eds.). Romance Languages and Linguistic Theory 2005: Selected papers from 'Going Romance', Utrecht, 8-10 December 2005. Amsterdam: John Benjamins, pp. 259-280.

Picallo, $M^{\mathrm{a}}$ Carme (1984). «The Infl node and the null subject parameter». Linguistic Inquiry 15: 75-102.

Prieto, Pilar (2002). «Entonació». In: Solà, Joan; Lloret, M. Rosa; Mascaró, Joan; Pérez-Saldanya, Manuel (dirs.). Gramàtica del català contemporani. Barcelona: Empúries, 393-462.

Torrego, Esther (1984). «On inversion in Spanish and some of its effects». Linguistic Inquiry 15: 103-129.

Vallduví, Enric (1992). The informational component. New York: Garland. 
Vallduví, Enric (2002). «L'oració com a unitat informativa». In: Solà, Joan; Lloret, M. Rosa; Mascaró, Joan; Pérez-Saldanya, Manuel (dirs.). Gramàtica del català contemporani. Barcelona: Empúries, 1221-1279.

Vallduví, Enric; Engdahl, Elisabeth. (1996). «The linguistic realisation of information packaging». Linguistics 34: 459-519.

Villalba, Xavier (2007). «La dislocació a la dreta en català i castellà: microvariació en la interfície sintaxi/pragmàtica». Caplletra 42: 53-68.

Villalba, Xavier (2011). «A quantitative comparative study of right-dislocation in Catalan and Spanish». Journal of Pragmatics 43: 1946-1961.

Villalba, Xavier; Mayol, Laia (2013). «Right-dislocation in Catalan: Tails, polarity and activation». International Review of Pragmatics 5: 87-117.

Ziv, Yael (1994). «Left and right dislocations: Discourse functions and anaphora». Journal of Pragmatics 22: 629-664.

Zubizarreta, M. Luisa (1998). Prosodic, focus, and word order. Cambridge, MA: MIT Press. 
